\title{
THE CORRELATION BETWEEN MOTIVATION BEHAVIOUR AND SPEAKING ABILITY
}

\author{
Diki Maulana $^{1}$, Widya Sri Wahyuni ${ }^{2}$, Detya Siregar ${ }^{3}$ \\ ${ }^{1}$ IKIP Siliwangi, Cimahi \\ ${ }^{2}$ IKIP Siliwangi, Cimahi \\ ${ }^{3}$ IKIP Siliwangi, Cimahi

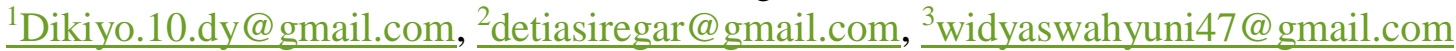

\begin{abstract}
This researchis aboutthe correlation between motivation behaviour and spekaing abilityat English Students Association. Hence, this research is aimed to find out whether or not there is a significant correlation between motivation behaviour and speaking ability at English Students Association. This research used correlation research design and qualitative research. The instrument is motivation test using questionnaire and speaking test by story telling. The population of this research is English Students Association of IKIP Siliwangi and the sample is 30 students. The data o this research is analysed using pearson product moment correlation coefficient. The degree of correlation between two variables was low with a correlation coefficient of 0.045. the result showed that there was a weak correlation between motivation behaviour and speaking ability at English Students Association.
\end{abstract}

Keywords: Correlation, Motivation Behaviour, Speaking Ability

\section{INTRODUCTION}

English is the one of language that can be used widely in the world, most of people using English as an international language. English is tought in all of schools in the world especially in Indonesia. In Indonesia, English as the third language because the first language is mother tongue from each cultures, and the second is Indonesian. According to Sadikin (2016, p.403) English as a foreign language in Indonesia has been introduced from primary to university level of education. As we know, English is tought here for facing a new globalization, people who cannot speak English will be left behind far away even for reach a successful.English has four skils such as Listening, Speaking, Reading, and Writing. The four language skills are then used as a measurement of a language comprehension. One of the examples is speaking skill.

Speaking is the one of skills that can be used in communication widely, in speaking especially give more information for people, it makes easier way to learn English spontaneously. Moreover, speaking is important to be mastered by people if they want to get a lot of informations. As stated by Brown(2004) in sidik (2013) emphasizes that speaking skill is a skill in producing an oral language. Speaking has some variable connections such as self- confidence, vocabulary, and motivation. One of examples is motivation behaviour.

Motivation behaviour is adesire of ourselves to know our goal to be come true, it can make someone has a good optimist to learn or to reach a fruitful. Motivation behaviour; where behaviour is understood as "anything a person does, typically in response to internal or external activities", is goaldirected and purposeful and it is therefore "difficult to think of any behaviour which is not motivated in this sense". 
From explainations above, motivation behaviour is important in making our goal especially mastering speaking English to be come true.Students who have motivation behaviour will have an aim why they should master speaking English.

The writers will conducted the Journal article entitle "The Correlation Between Motivation Behaviour and Speaking Ability". This Journal article will be held at IKIP Siliwangi. The population is English Students Association and the sample is thirty students. In this occasion, we can see that students who do not have a motivation, they are less in speaking English, so the teacher should give them more motivation to learn. Students will not be able to speak English if they do not have a motivation. Motivation is important for students to be more active in learning activities.

\section{Motivation Behaviour}

Motivation is identified as a fundamental aspect of learning (Brewer \& Burgess, 2005). Gredler, Broussard and Garrions (2004) broadly define motivation as "the attribute that moves us to do or not to do something" intrinsic motivation that is animated by personal enjoyment, interest or pleasure. As Deci et al. (1999) observe, "intrinsic motivation energizes and sustains activities through the spontaneous satisfactions inherent in effective volitional action. Motivation will lead to actions; specifically, motivation to learn is characterized by long-term involvement in learning (Ames, 1990).

According to Ryan \& Deci (2000)Self-Determination theory distinguishes different types of motivation based on the different reasons or goals that give rise to an action. The most central disinction is between intrinsic motivation and extrinsic motivation.

\section{a. Intrinsic and Extrinsic Motivation}

1) Intrinsic motivation is the tendency to engage in task because one finds them interesting and enjoyable. Student with more intrinsic motivation tend to persist at difficult problems and learn from mistake. (Walker, Greene \& Mansell, 2006).

2) Extrinsic motivation is the tendency to engage in task-unreleated factors such as the expectation of reward or punishment, for example, to past the exam or get a good grade (Vansteenkiste, Lens \& Deci, 2006)

\section{Speaking Ability}

As stated by Brown (2004) in Sidik (2013) emphasizes that speaking skill is a skill in producing an oral language. Nunan (1991, p.39) in Sidik (2013) stated that mastering the art of speaking is the single most important aspect of learning the second or foreign language, and success is measured in termsof the ability to carry out the language conversation in language.

Caroline (2005:45) states that speaking is a basic oral communication among people in society.Moreover, Kayi (2006:1) states that speaking is the process of building and sharing meaning through the use of verbal and non-verbal in variety of context. It can be concluded that speaking is a basic oral communication to acquire the informations or ideas.

Brown (2004: 141) cites five stages of speaking performance. They are imitative, intensive, responsive, interactive, and entensive. The explanation about those categories is stated as follows:

a. Imitative: the ability to simply imitate a word or phrase or possibly a sentence.

b. Intensive: the production of short stetches of oral language designed to demonstrate competence in narrow band of grammatical, phrasal, lexical or phonological relationship. 
c. Responsive: this performance includes interaction and test comprehension, but at the somewhat limited level of very short conversation, standart greetings, small talk, simple request and comments.

d. Interactive: in this stage, the length and complexity of the conversation is more then responsive stage, which sometimes includes multiple exchange and/or multiple participants.

e. Extensive: extensive oral production includes speeches, oral presentations and story telling.

\section{METHOD}

This chapter describes the research methodology of this research. At this chapter consist of research design, setting of this research including population and sample, instrumentation, technique of collecting the data and technique of analyzing the data.

The design of this research is a descriptive qualitative Research and applies a correlative research. Ideally the variable has ratio level of measurement". Meaning that correlation research is the research will focuson two variable and found the relation both of them.

This research has two variable they are variable $\mathrm{X}$ and variable $\mathrm{Y}$. $\mathrm{X}$ variable is students' motivation and $\mathrm{Y}$ variable is speaking skill.Population of this reseach was population of the English Students Association, For sample of this research, the researchertookthirty students.

\section{Instrument and Technique Collecting the Data}

This research using questionnaire and speaking test.

In this research, to get the data about students' motivation and speaking skill, the researcher used three technique, they were quistionire and test.

\section{a. Questionnaires}

Questionnaires were used by researchers to convert into data the information directly given by a person (subject).Further more, it states that questionnaires are a way of getting data about persons by asking them rather than watching them by sampling abet of their behaviour. However, this questionnaiers are adapted from Jones (2001). It consists of many items of statements involving attitude and motivation but the researcher only took 30 items which are suitable with this. The questionnaires are "closed", it means the respondents are only choosing the best one on the items and making checklist on the given answers. In answering the questionnaires, the students are asked to choose one of the options by giving a mark or checklist. These are the components of indicators on students' motivation.

Table 1. Questionnaire

\begin{tabular}{|c|c|c|c|c|c|c|}
\hline $\mathrm{NO}$ & STATEMENT & SA & A & $\mathrm{N}$ & $\mathrm{D}$ & SD \\
\hline 1 & $\begin{array}{l}\text { I always practice English everyday } \\
\text { (saya selalu latihan bahasa Inggris setiap hari) }\end{array}$ & & & & & \\
\hline 2 & $\begin{array}{l}\text { I never practice English } \\
\text { (saya tidak pernah latihan bahasa Inggris) }\end{array}$ & & & & & \\
\hline 3 & $\begin{array}{l}\text { When I have trouble in learning English, I always ask to the } \\
\text { lecturer } \\
\text { (ketika saya punya masalah dalam pembelajaran bahasa Inggris, } \\
\text { saya selalu tanyakan ke dosen) }\end{array}$ & & & & & \\
\hline 4 & $\begin{array}{l}\text { When I have trouble in learning English, I never ask to the } \\
\text { lecturer } \\
\text { (ketika saya punya masalah dalam pembelajaran bahasa Inggris, } \\
\text { saya tidak pernah tanyakan ke dosen) }\end{array}$ & & & & & \\
\hline 5 & $\begin{array}{l}\text { I am directly doing English exercise that had been given } \\
\text { (saya mengerjakan soal latihan bahasa Inggris yang telah }\end{array}$ & & & & & \\
\hline
\end{tabular}


Motivation...

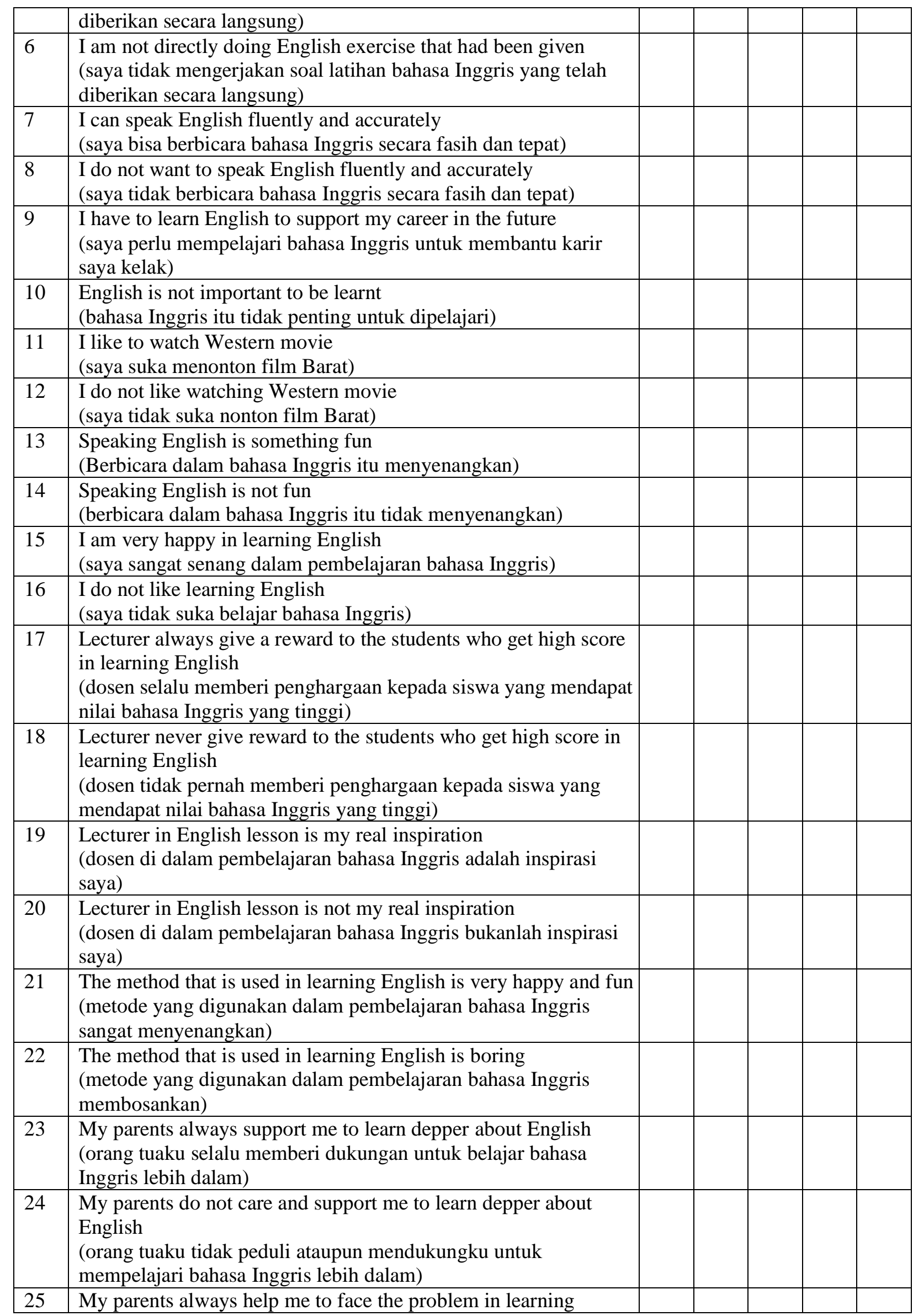




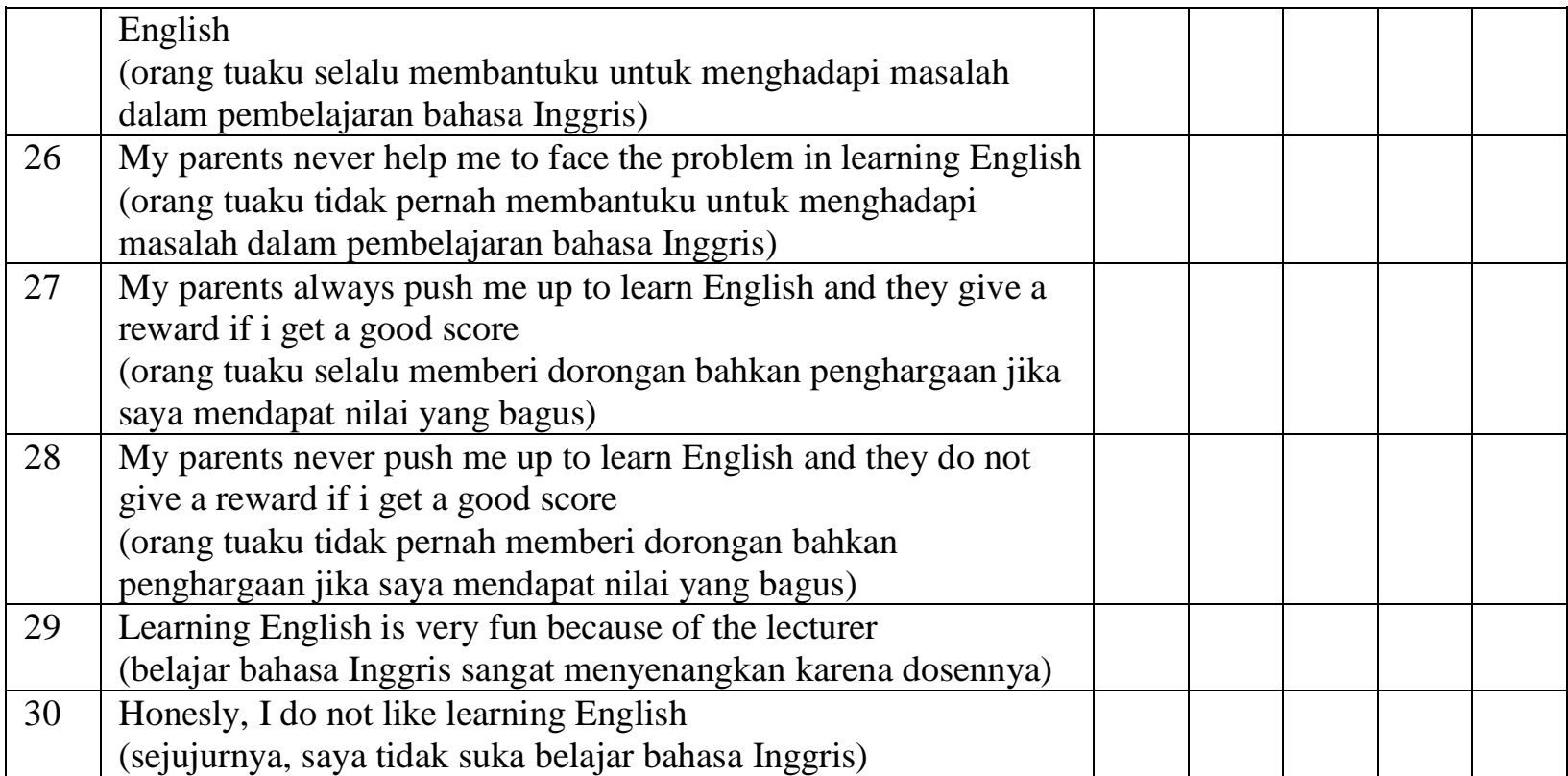

Adapted from Jones (2001)

Adapted from Jones, Holly Kristine, 2001.Academic Self-Confidence Scale: A Psychological Study in Two Parts. University of Tennessee, Knoxville

Table 2. The Likert Scale Rating

\begin{tabular}{|c|c|c|}
\hline \multirow[b]{2}{*}{ Option } & \multicolumn{2}{|c|}{ Score } \\
\hline & Positive Statement & Negative Statement \\
\hline Strongly Agree & 5 & 1 \\
\hline Agree & 4 & 2 \\
\hline Neutral & 3 & 3 \\
\hline Disagree & 2 & 4 \\
\hline $\begin{array}{l}\text { Strongly } \\
\text { Disagree }\end{array}$ & 1 & 5 \\
\hline
\end{tabular}

\section{b. Speaking Test}

To test the students speaking skill the researcher was used performance test, the test was to measure the students skill in speaking, than the test was distributed to the students by giving them a topic and ask them to speak in front of others about everything they know based on the topic. The topic that was distributed to them as follows :

\section{Tabel 3. The Topic Speaking Test}

\begin{tabular}{|l|l|l|l|}
\hline No & Topic & Duration Speaking & Note \\
\hline 1 & $\begin{array}{l}\text { The activities of English Students } \\
\text { Association }\end{array}$ & 3 Minutes & \\
\hline 2 & $\begin{array}{l}\text { The Events of English Students } \\
\text { Association }\end{array}$ & 3 Minutes & \\
\hline
\end{tabular}


The researcher give them 3 minutes for each students. The researcher was recorded and write down the manuscrip of the students' speaking skill. However in measuring their ability in speaking, the reseracher used Hughes (2003:131) the indicator of the speaking. In addition Hughes (2003:131), also presented the sample of an oral proficiency scoring categories rating that is used 1-5 points.

\section{Result and Discussion}

\section{Result}

\section{a. Students' Speaking test}

Speaking test consisted of story telling test for 3 minutes for each students.

b. Questionnaire

Questionnaire consisted 30 items to be answered by students.

Table 4. Students' Score

\begin{tabular}{|c|c|c|}
\hline Students & Speaking Test & Questionnaire \\
\hline 1 & 80 & 90 \\
\hline 2 & 80 & 87 \\
\hline 3 & 80 & 91 \\
\hline 4 & 80 & 87 \\
\hline 5 & 80 & 88 \\
\hline 6 & 60 & 81 \\
\hline 7 & 80 & 81 \\
\hline 8 & 60 & 90 \\
\hline 9 & 90 & 85 \\
\hline 10 & 60 & 85 \\
\hline 11 & 80 & 84 \\
\hline 12 & 60 & 84 \\
\hline 13 & 80 & 75 \\
\hline 14 & 80 & 87 \\
\hline 15 & 60 & 90 \\
\hline 16 & 80 & 87 \\
\hline 17 & 80 & 90 \\
\hline 18 & 80 & 93 \\
\hline 19 & 90 & 84 \\
\hline 20 & 90 & 84 \\
\hline 21 & 90 & 87 \\
\hline 22 & 90 & 81 \\
\hline 23 & 80 & 82 \\
\hline 24 & 90 & 93 \\
\hline 25 & 60 & 87 \\
\hline 26 & 60 & 84 \\
\hline 27 & 90 & 81 \\
\hline 28 & 50 & 75 \\
\hline 29 & 80 & 81 \\
\hline 30 & 90 & 75 \\
\hline
\end{tabular}

From the table students' scores above the writers will find the descriptive statistics. 
Table 5. Descriptive Statistics

\begin{tabular}{|c|c|c|c|c|c|c|c|c|}
\hline & $\mathrm{N}$ & Range & Minimum & Maximum & \multicolumn{2}{|c|}{ Mean } & Std. Deviation & Variance \\
\cline { 2 - 8 } & Statistic & Statistic & Statistic & Statistic & Statistic & Std. Error & Statistic & Statistic \\
\hline Speaking & 30 & 40 & 50 & 90 & 77,00 & 2,205 & 12,077 & 145,862 \\
Motivation & 30 & 18 & 75 & 93 & 84,97 &, 891 & 4,881 & 23,826 \\
Valid N & 30 & & & & & & & \\
(listwise) & 30 & & & & & & & \\
\hline
\end{tabular}

From the table above, there are 30scores both of speaking test and motivation questionnaire. The range of speaking is 40 and 18 for motivation. The minimum score of speaking is 50 and 75 for motivation. The maximum score of speaking is 90 and 93 for motivation. The mean of speaking is 77.00 and 84.97 for motivation. Standard deviation of speaking is 12.077 and 4.881 for motivation. Variance of speaking is 145.862 and 23.826 for motivation.

Table 6.One-Sample Kolmogorov-Smirnov Test

\begin{tabular}{|ll|r|rr|}
\hline & & Speaking & \multicolumn{2}{|c|}{ Motivation } \\
\hline N & & 30 & 30 \\
Normal & Mean & 77,00 & 84,97 \\
Parameters ${ }^{\mathrm{a}, \mathrm{b}}$ & Std. Deviation & 12,077 & 4,881 \\
Most Extreme & Absolute &, 331 &, 128 \\
Differences & Positive &, 187 &, 079 \\
& Negative &,- 331 &,- 128 \\
Test Statistic & &, 331 &, 128 \\
Asymp. Sig. (2-tailed) &, $000^{c}$ &, $200^{\mathrm{c}, \mathrm{d}}$ \\
\hline
\end{tabular}

a. Test distribution is Normal.

b. Calculated from data.

c. Lilliefors Significance Correction.

$\mathrm{d}$. This is a lower bound of the true significance.

From the table above, mean of speaking test is 77.00 and 84.97 for motivation, standard deviation of speaking is 12.077 and 4.881 for motivation. $\mathrm{N}$ is the number of sample, significant number of speaking is 0.000 and 0.200 for motivation with significant value 0.05 .

Normality test result shows that significant number of speaking test score is lower than the level of significant $(0.000<0.05)$, and significant number of motivation score is $(0.200>0.05)$. It means that students' score of speaking and motivation are almost in normal distribution. After testing the normality value, the writers try to find out the correlation between motivation behaviour and speaking ability.

Table 7. Correlations

\begin{tabular}{|ll|c|c|}
\hline & & Speaking & Motivation \\
\hline Speaking & Pearson & 1 &, 045 \\
& Correlation & &, 813 \\
& Sig. (2-tailed) & & 30 \\
N & 30 & \\
\hline
\end{tabular}




\begin{tabular}{|ll|r|rr|} 
Motivation & Pearson &, 045 & 1 & \\
& Correlation & & & \\
& Sig. (2-tailed) &, 813 & & \\
$\mathrm{~N}$ & & & \\
\hline
\end{tabular}

Based on the table above, seen that the value of correlation coefficient is 0.045 , it means the pearson product moment coefficient correlation is low correlation between motivation behaviour and speaking ability because from the table above we know score of significant 0.813 and more than 0.05 , in other words, the Alternative hypotesis (Ha) is rejected and Null hypotesis (Ho) is accepted. It means that there is no a correlation between motivation behaviour and speaking ability.

\section{Discussion}

As it has been already described above, the purpose of this journal paper was to determine the correlation between motivation behaviour and speaking ability. The writer was conducted to answer the question is there any correlation between motivation behaviour and speaking ability by giving questionnaire of motivation and story telling of speaking test conducted at English Students Association.

Based on the table scores of motivation and speaking test, the result of tests were given to English Students Association is almost normal, becuase the test result shows that significant number of motivation test is higher than level of significant $(0.200>0.05)$, also significant number of speaking test score is lower than level of significant $(0.000<0.05)$. It means that motivation behaviour and speaking ability are almost in normal.

The value of correlation coefficient is 0.045 , it means the pearson product moment coefficient correlation is low correlation between motivation behaviour and speaking ability. Based on table of sig. (2-tailed) is 0.813 and more than 0.05 . It means that motivation behaviour and speaking ability there is no correlation.

One of difficulties of students in speaking is less of motivation and the teacher should give them a motivation as well. Students can be more active if they have a lot of motivation in their learning activities.

\section{Conclusion}

Based on the discussion and the result above of the research, this research uses correlation research of pearson product moment correlation coefficient using two variables; motivation behaviour and speaking ability. The writer conducted to find whether there is a correlation between motivation behaviour and speaking ability of English Students Association. As we can see that motivation is important for students but not influence a lot of speaking, students who have a higher motivation also can speak fluently among they who do not have it. It means that motivation is important for them who want to learn especially in speaking. They need to put their motivation in their life because it recognizes them as their own abilities. As we can see students who have a motivation, they also have an optimist to do something. Moreover, they can be active especially in learning activities. Teacher is the one who can lead students to get a motivation at school.

From the data collected above the writer can be concluded there is no a normal distribution because the test result shows that significant number of motivation score is higher than level of significant $(0.200>0.05)$, and significant number of speaking test score is lower than level of significant $(0.000<$ $0.05)$. It means that motivation behaviour and speaking ability are not normal distribution. 
Based on table of sig. (2-tailed) is 0.813 and more than 0.05 . And the value of correlation coefficient is 0.045 , it means the pearson product moment coefficient correlation is low correlation between motivation behaviour and speaking ability. In other words, the Alternative hypotesis (Ha) is rejected and Null hypotesis (Ho) is accepted. It means that motivation behaviour and speaking ability there is no correlation.

\section{References}

Ames, C. A. (1990). Motivation: What teachers need to know. Teachers College Record. 91(3), 409-421.

Brewer, E. W., \& Burgess, D. N. (2005). Professor's role in motivating students to attend class. Journal of Industrial Teacher Education, 42(3), 24.

Broussard, S. C., \& Garrison, M. E. B. (2004). The relationship between classroom motivation and academic achievement in elementary school-aged children. Family and Consumer Sciences Research Journal. 33(2), 106-120.

Brown, H. D.(2004). Language Assessment Principles and Classroom Practice. New York. Pearson education.

Caroline T. (2003). Practical English Language Teaching Young Learners. New York: Mc. Graw. Hill.

Deci, E. L., Koestner, R., \& Ryan, R. M. (1999). A meta-analytic review of experiments examining the effects of extrinsic rewards on intrinsic motivation. Psychological Bulletin,125(6), $627-668$.

Hughes, A.(2003). Testing for Language Teachers. Cambridge: Cambridge University Press.

Jones, H. K. (2001). Academic Self-Confidence Scale: A Psychological Study in TwoParts. University of Tennessee, Knoxville.

Kayi, H.(2006). "Teaching Speaking : Activities to Promote in Second language". TSL Journal. Vol. 12. Retrieved from: http:/itslj.org.article/kayi teaching.Html

Kusmaryati, S. E. (2009). Improving English Speaking Ability Through Classroom

Discussion For Students Of Ma Nu Banat Kudus In The Academic Year 2008/2009. Universitas Maria Kudus. Published.

Ryan, R. M., \& Deci, E. L. (2000). Intrinsic and extrinsic motivations: Classic definitions and new directions. Contemporary Educational Psychology, 25, 54-67.

Sadikin, I. S. (2016). The use of Webquest for Teaching English Vocabulary in an Learners Context.In Prosiding ICTTE FKIP UNS 2015. Semarang State $1(1), 403-410$.

EFL Young University.

Sidik, A. S. (2013). Improving Students' Speaking Ability Through Practice Rehearsal Pair of The Tenth Grade of Man Malang 1. Language-Edu.2(4), 682-688.

Vansteenkiste, M., Lens, W., \& Deci, E. L. (2006). Intrinsic versus extrinsic goal contents in selfdetermination theory: Another look at the quality of academic motivation.Educational Psychologist, 4l(1), 19-31. 
Walker, C., Greene, B., \& Mansell, R. (2006). Identificat ion with academics, intrinsic/extrinsic mot ivation, and self-efficacy as predictors of cognitive engagement. Individual Differences, 16(1), 1- 12. 